University for Business and Technology in Kosovo

UBT Knowledge Center

UBT International Conference

2013 UBT International Conference

Nov 2nd, 5:30 PM - 5:45 PM

\title{
Appeals as one of the fundamental human rights
}

Blerim Krasniqi

Follow this and additional works at: https://knowledgecenter.ubt-uni.net/conference

Part of the Law Commons

\section{Recommended Citation}

Krasniqi, Blerim, "Appeals as one of the fundamental human rights" (2013). UBT International Conference. 51.

https://knowledgecenter.ubt-uni.net/conference/2013/all-events/51

This Event is brought to you for free and open access by the Publication and Journals at UBT Knowledge Center. It has been accepted for inclusion in UBT International Conference by an authorized administrator of UBT Knowledge Center. For more information, please contact knowledge.center@ubt-uni.net. 


\title{
Apeals s as one of the fundamental human rights
}

\author{
Berat Aqifi , A. Emini, \\ berataqifi@hotmail.com; berat.aqifi@ubt.uni.net.com \\ Lecturer, Faculty of Law, University "UBT", Prishtina, Kosova \\ ardian.emini@ubt.uni.net.com \\ Lecturer, Faculty of Law, University "UBT", Prishtina, Kosova
}

\begin{abstract}
In this paper we treat maters of proposals and apeals s, ie conditions and their apeals procedure to the competent body, set as a basic right of humanity in accordance with the constitution, law and other articles, apeals $\mathrm{s}$ by the party whose rights have been violated with different procedures that occur by the State admistrative body.

The right for apeals s to the highest state authorities, dates back to the early ages, in the beginning was presented as a request in a humiliating manner and up to the fun damental right that was treated in many documents of the democratic countries.

Looking at the historical aspect of treating apeals role from the past till present, not many countries in their constitutions or special laws regulate this important matter for the citizens, as one of the most democratic forms of expression of revolt in writing and civilization to the work of state bodies.

The protection of fundamental human rights, although guaranteed by international acts and other internal acts of certain states, they are continually violated, a matter that paves the way for Ombudspers on or other government to enable their citizens with a chance to protect their rights.
\end{abstract}

Keywor ds: apeals, proposal, human rights, ombudspers on, local governance

\section{Introduction}

Protection of personal rights and interests of citizens in the past has driven them to address the governmental bodies in whatever level, by using the instruments envisioned at various documents to make them reply orally or written with the aim to protect those rights.

Today, looking from the time perspective, this right for submitting the appeal is regulated by law and guaranteed to every legal person, and for those didn't not draw any responsibility or have any consequence for the purpose of presenting the complaints.

Bodies which are acting according to requests and proposals are obliged to act within the time limits set by law.

\section{History Of Presenting Complaints And Proposals}

\subsection{The Roman Empire}

In historical terms the right of complaints in the past played an important role in the development of social and political life in Roman Empire. Its presentation importance and form takes especially during the reign of Emperor Jul Caesar, as presenters at a meeting in Senate (as the highest body at the time of the Roman Empire) in the year $44 \mathrm{BC}$, which had a paradoxical position.

\section{The role and importance of law in the time of submissions}

The first one who initially presented and submitted the requests as a sign to some form of compromise or arrangement was Senator Tilius Kimberi. In the Roman era dictionaries for submissions can be found under the term definition as "suplicare or suplikacion", derived from the Latin word meaning supplicare "demeaning request". 
Over the time requestss take other form of expression which means not only a simple request or appeal, but it expresses a special form of legal instrument. During the reign of the Roman Empire within state authorities it had a special committee for award of replies for such requests.

\subsection{The Middle Age}

\subsection{Legal sources in England}

During medieval the roots or base of the right for requests can be found in England in some early documents as following:

\section{Magna Carta Libertatum - year 1215}

Magna Carta Libertatum of the year 1215, over the years expressed on of the main and formal documents of legal system in England of that time, where it had some of the elements of the rights to the requests.

In Magna Carta Libertumaccording to the translated version in contemporary English it defines "If we as the main Judges or someone among our servants

From this part of this document it can be supposed that even the power was trusted to 25 inhabitants elected by the king, these inhabitants had some authorizations to submit the requests up to the king, if they consider that it has been made any violence or injustice which is mentioned into the document.

\subsection{Bill of Rights of 1689}

This catalog of freedom, the so-called Bill of Rights of 1689, which ended the absolutist rule in Great Britain and established constitutional monarchy, gives Parliament the right to freedom (free elections, the right to freedom of speech, the right tax).

Bill of Rights - contains rules which significantly and absolutely limit the power and guarantee greater protection of human rights. He declared the power illegally that seeks to suspend the law or rule without law: entitles citizens to submit petitions to the king and declared unlawful imprisonment orders or prosecution of those who have filed petitions, prohibits inhuman and unusual punishments.

Upon the time the right to submit a request takes place in a special document called Bill of Rights, this statement foresaw that "subjects or citizens under the rule of the king had the right to submit requests and they have no fear that they will be tracking to them".

\subsection{USA}

Declaration of Independence of the United States of America - (1776)

Declaration of Independence of the United States of America prepared by Jefferson

approved on 4 July 1776 , states:

- That all persons are created equal:

- That their Creator has given some undisputable rights, such as life, liberty and the pursuit of happiness;

- That governments are created to secure these rights

The Declaration proclaims the right of the people at any time when any form of government becomes obstacle to be embodied these purposes, suspend or commute to and form a new government based on principles and with such a power such as appear most best to achieve freedom and happiness.

Based on developments in England in the U.S. the right to petition was regulated in the first Amendment to the U.S. Constitution in 1789 by James Madison where he was provided the right to petition.

\subsection{Germany}

In Germany the right to petition was initially regulated by law since 1794 and that by Codex General Law of Prussia. 
German constitution The Basic Law (Grundgesetz) of 1949 as an example that provides broad protection where the first 20 articles of the Constitution, dedicated to human rights, the right to $\mathrm{i}$ the petition is a guaranteed institute in Article 17 of the Basic Law which asserts that: "Everyone has the right, individually or jointly with others, to address written requests or complaints to the competent agencies and to parliaments .

\subsection{France}

Declaration of the Human Rights and Citizens of the year 1789

French National Assembly on 26 August 1789 adopted the Declaration on Human Rights and the Citizens, according to which "people are born and live free and equal in rights"

Human rights are confirmed by this statement, specifying and expanding the Declaration on Human Rights and the Citizens, of the year 1793, which repeats the principles of the Declaration of 1789, and also contains several new human rights such as:

- The right to file petitions to public institution providers;

- $\quad$ The right to revolt,

- The right of peaceful assembly and to exercise religious rites

\section{The elements of the right to submit the requests and proposals}

\subsection{The right to submit the requests and proposals from formal and legal aspect}

Viewed from formal and legal aspect the right to submit the requests is supposed to have some components (elements) as in the following:

1. The first component or element is that the right to submit requests up to legis lator body - the parliament, or the executive body - the government, and other competent state bodies is a guaranteed right that belongs to every citizen of the Republic of Macedonia, as personal or collective right.

2. The right of submission of complaints to authorities, supposedly brings no regular legal remedies or other means, but only a request form that according to the law, the competent authority is obliged to respond the deserved answer at the time specified by law.

3. The submission of the appeal with regards to specific request, it musnt not show any fear for the respective applicant, as regarding the realization of this right.

These elements in a clear mannaer are explained in the constitution of Macedonia set by the act 24 "every citizen has the right to submit apleals at the state officials for services and other public services and shall receive a response. The citizen can not be held responsible, or harmed because of the submitted apeal, unless the citizen has performed misconduct".

As it can be seen, the constitution of RM in a straightforward forsees apeals s to the state officials are set with the highest act, this right is in line with basic rights of citizens.

The right of apealss and proposals to other government body

In regards to the apeals and proposals, every citizen has the right alone or with others for apeals and proposals for the work of officials of the municipality or municipal administration.

3.2 The rol of municial mayors about apeals $s$ and proposals

In his frameworkd, the mayor is obligated to:

- To create conditions for the delivery of apeals and proposals;

- The turn around response is 60 days from the acceptance day (proposal), ensuring that response is sent to the requestor and, 
- Apeals and proposals that are not related to the municial work, the individual that is subbmiting the appeal shall be informed.

\subsection{The role of people's advocate for apealss and proposals}

Ombudsperson or peoples advocate in judicial system of many countries is a result of many needs to protect peoples rights.

Main function of the people's advocate is determined by the law and the consitiution. As an insititution that protects constitution and legal rights when they are violated citizen's rights by the government administration (for example, from ministries, directorates, commissions) and other authorized public bodies.

Every person, that evaluates or considers that his constitutional rights have been violated, and more specific when dealing with basic righs for non-discrimination fair and adequate representation of party members in the above mentioned government bodies, the apeals can be handed to ombudsperson. The ombudsperson can call for a procedure with self initiative, if it considers that rights have been violated. Apeals handed to the obmbusperson must be signed by the submitting individual, to contain personal data, explanatory, facts, proof that apeals is based on. The apeals is delivered in writing or verbally through recording process in writing and it's free of charge.

According to act 29 of order for office work and archive ("Gazeta zyrtare e RM-së" nr. 58/96) , Obudsperson approves: LIST for documentation proof and storing timelines for the year 2008 and ombudsperson insititution:

For: The rights and civil freedoms of the community groups

- Apeals from police procedure area; procesuctor; judical; from defence area; violation of the principles of non-discrimination and adequate and equitable representation of community members,

\section{Rights protection and social security where they belong:}

- Appeals from the field of health insurance; social rights, in the field of pension and disability insurance; for violation of the rights of children, in the field of education and science and the field of culture and sport.

- Appeals from the field of property law; Complaints field of urban planning and construction; Appeals issues in the field of shelter; apeals of customs and finance areas;

- Notification, recomandation, proposals and other acts 5 years

- Appeals from employment; Appeals area of consumer rights; Complaints from the field of the environment;

- Appeals fromthe field of property law; Appeals in the field of urban planning and construction; Appeals issues in the field of shelter; Appeals in the field of customs and finances;

- Announcements, recommendations, proposals, opinions and other acts 5 years

\subsection{Role of Municipalities about apeals s and proposals}

To strengthen civil society function and responsibility of public authorities, The law contains provisions for local self-government for the right of citizens to submit complaints and proposals for the work of the municipal administration, as well as the obligation of the authority concerned to answer with explanation applicant, later within 60 days of receipt.

In case of working on issues that are not part of municipality responsiblity, the municipal body is obliged to submit the same to the competent authority and notify the apealsant for this matter.

Statute as the highest legal act that is approved by the Municipality and in accordance with legislation of central government that regulates the internal organization of the municipality as a basic unit fun ction in the territory of Republic of Kosova, in accordance with the law: how about presenting apeals and proposals for the work of municipal bodies and acted upon. 
The law for local self adminstration in act. 29 provides that appeals and proposals has the right to represent every citizen is entitled separately and jointly with others submit submit complaints jointly with others apeals $\mathrm{s}$ and proposals for the work of municipal bodies and municipal admin istration.

\subsection{Role of Mayors about apeals s and proposals}

\section{Within its competence the Mayor is obliged:}

- To create conditions for the apeals of complaints and proposals;

- The turn around response is 60 days from the acceptance day (proposal), ensuring that response is sent to the requestor and,

- Apeals $\mathrm{s}$ and proposals that are not related to the municial work, the individual that is subbmiting the subbmmission shall be informed.

Handling of complaints and proposals on Kosovo

Regarding the Handling of complaints and proposals in Kosovo, unlike legal practices in the region and beyond, were treated as above, Law in Kosovo this institute special importance as one of human rights addressed in many democratic countries and world leu, we find only documents PZAP as a permanent body, independent and competent to make decisions in regards to appeals that are authorised with the election process set in accordance with the law of Republic of Kosova and Election rules.

\section{Conclusion}

- Initially the appeals that were presented were demeaning,

- Inspired from EU countries and USA, as far as the appeals and proposals from regional countries, R. E. Macedonia has has issued a law that regulates the precise issue of apeals of complaints and suggestions, and the form of actions which should undertaken, the protection of human rights has issued a law that regulates the precise issue of apeals of complaints and suggestions, obliging the other associated bodies of state administration and public ombudsman etc.

- Apeals s occur singly and in groups, that its claimant can not invoke the liability or other consequences, unless it has made any incriminating act according to the law.

- The body has since admitted that the complaint is obliged within 15 to 30 days, if the petition contains actual legal requirements or notes that are flagrantly violated legal provisions, to respond to the complaint.

- Bodies under the law are always compelled to record for each application that deals with complaints and prepare reports every six months to the Ministry of Justice

\section{References}

1. Zejnullah, Gruda, Mbrojtja ndërkombëtare e të drejtave të njeriut, Prishtinë. 2010

2. A.Borkowski\&P de Plesis, Roman Law. 2004

3. Ortlieb Fliedner, Seminar për zbatimin e legjislacionit ë ri, Shkup, Qershor 2009

4. Constitution of the SFRY, 1974

5. Constitution of the Republic of Macedonia, 1991

6. Constitutional Law on Implementation of the Constitution of the RM, 1991

7. Law on General Adminis trative Procedure

8. Law on Local Vetadiminstrim Republic of Macedonia, 2002

9. Order stationery and archival work ("Official Gazette" no. 58/96)

10. People's LigjipërAvokatin ("GazetaZyrtare of RepublikëssëMaqedonisë" no. 60/03)

11. Law of the Republic of Kosovo Elections and Electoral Rules

12. Constitution of Germany, The Basic Law (Grundgesetz) Article 17, 1949 
13. Constitution of Germany, The Basic Law (Grundgesetz), 2009

14. Law on the Rights of 1689

15. Constitution of the United States 1789Magna Carta Libertum e vitit 1215, MAGNA CARTA THE GREAT CHARTER OF ENGLISH LIBERTY DECREED BY KING JOHN AT RUNNYMEDE JUNE 15, A.D. 1215

16. http://www.syri3.com/index.php?id_kat $=17 \&$ shkrimi $=693$

17. http://en.wikipedia.org/wiki/Lucius_Tillius_Cimber

18. http://www.legis lature.mi.gov/(S(rdmzrh45cfzav $145 \mathrm{rvwfoh} 2 \mathrm{q})) /$ documents/his torical/magna carta.htm\#2

19. http://www.dadalos.org/alb/parteien/grundkurs4/GB/regierungssystem.htm

20. http://www.servat.unibe.ch/icl/gm01000_html

21. http://www.scribd.com/doc/39601040/KÜSHTETUTA-E-REPUBLIKES-SEMAQEDONISE-ME-AMENDAMENTET-E-KUSHTETUTES-I

22. http://www.balkanweb.com/ 